\title{
ALL-UNION GEOLOGICAL INSTITUTE RADIOCARBON DATES I*
}

\section{Kh. A. ARSLANOV, L. I. GROMOVA, and Yu. A. RUDNEYEV}

Laboratory for Quaternary Geochronology of the

All-Union Geological Research Institute, Leningrad

For determining age scintillation variant was used. Measurement of a large quantity of benzol [benzene]** permitted reaching a limit of $62,000 \mathrm{yr}$ without isotope enrichment. Precautions against contamination of the samples with contemporary carbon and tritium were taken in laboratory handling. Dating began only after it had been established that contamination had not taken place during chemical treatment. Benzol which displayed no radioactivity was synthesized from anthracite. Special measures were taken to remove humic acids from the sample by boiling the powdered sample for three days with three fresh lots of $2 \%$ solution of $\mathrm{NaOH}$ (Arslanov et al., 1966a, p. 134).

\section{Yaroslavl' Oblast}

\section{LG-1. Dolgopolka River, Yaroslavl' Oblast}

Wood from interglacial sediments in terrace at mouth of Dolgopolka R., tributary of Volga R., at Otmishchevo village [ $57^{\circ} 55^{\prime} \mathrm{N}$ Lat, $39^{\circ} 25^{\prime}$ E Long], $4 \mathrm{~km}$ above Tutayev, Yaroslavl' Oblast, from layer of humified alluvium ca. $1.5 \mathrm{~m}$ above water surface. Coll. 1965 by Kh. A. Arslanov, All-Union Geol. Inst., Leningrad, Ye. P. Zarrina, I. I. Krasnov, and V. A. Novskiy.

\section{Cheremukha River series}

This series of measurements was undertaken to fix geological age of deep lacustrine deposits in test section of Cheremukha $\mathrm{R}$. The critical stratum is overlain by $7.5 \mathrm{~m}$ of sand. It constitutes a brown-black peaty alluvium, $1.25 \mathrm{~m}$ thick with abundant plant remains. Immediately above water level is base stratum $0.3 \mathrm{~m}$ thick, of silty gray sand with tree trunks.

Pollen analysis of peaty stratum indicated interstadial climatic conditions which were dated as Mologo-Sheksnya (Paudorf) on basis of 2 determinations: LE-70A $=35,360 \pm 400 \mathrm{yr}$ (Arslanov et al., 1966a, p. 135) near top of peaty layer, and LE-66A $=46,270 \pm 1240 \mathrm{yr}$ (ibid.) at base of gray silty sand. In the present series 1961 determinations (Sukachev et al., 1961) have been reworked on basis of 1965 samples (LG-6A and LG-3A) and show that deposits are older than Mologo-Sheksnya (Arslanov et al., 1966a). [D.B.S.]

LG-6A. Cheremukha River

Wood from interglacial lacustrine sediments in flood-plain terrace of Cheremukha R., $8 \mathrm{~km} \mathrm{~S}$ of Rybinsk [58 $00^{\prime} \mathrm{N}$ Lat, $39^{\circ} 00^{\prime}$ E Long].

* Submitted as part of Radiocarbon Dates from Soviet laboratories, 1 January 1962-1 January 1966. See p. 417, this issue. (D.B.S.).

** Information in brackets interpolated by translator (E.M.S.) and commentator 
Sample from layer of peaty alluvium with many plant remains, at depth 7.5 to $7.8 \mathrm{~m}$ below terrace surface. Coll. 1965 by Kh. A. Arslanov, Ye. P. Zarrina, I. I. Krasnov, and V. A. Novskiy. Comment (D.B.S.): given stated limit of measurements at this laboratory, the indeterminate date presumably represents effects of inadequate sample size; (Cf. also Mo304, Vernadsky Inst. IV-V, 1968).

LG-6B. Cheremukha River $>38,600$

Humic acids extracted from Sample LG-6A. Comment (D.B.S.): relatively low age indicates secondary origin for acids; (Cf. Arslanov et al., 1966a, p. 134).

LG-3A. Cheremukha River

Wood from lower stratum, gyttja, at level of Volga R.

LG-3B. Cheremukha River

Humic acids extracted from Sample LG-3A.

\section{Chermenino series}

LG-5. Chermenino, Yaroslavl' Oblast

Wood from upper strata of interglacial lacustrine sediments, in terrace of Volga R. at Chermenino village, $9 \mathrm{~km}$ below Rybinsk [58 $04^{\prime}$ $\mathrm{N}$ Lat, $38^{\circ} 52^{\prime}$ E Long]. From gyttja at depth 2.2 to $2.5 \mathrm{~m}$ below terrace surface and beneath veneer of alluvium. Coll. 1965 by Kh. A. Arslanov, Ye. P. Zarrina, I. I. Krasnov, and V. A. Novskiy. (Cf. MO-307, Vernadsky Inst. IV-V, 1968 and Le-64, Khlopin Inst. I, 1968).

\section{LG-4A. Chermenino, Yaroslavl' Oblast}

Wood from same exposure, at depth $4.8 \mathrm{~m}$, in middle part of stratum of interglacial sediments (sand with shells and plant remains).

\section{LG-4B. Chermenino, Yaroslavl' Oblast}

$37,850 \pm 760$

Humic acids extracted from specimen LG-4A. Comment: sample apparently contaminated by humic acids from overlying younger sediments.

\section{LG-8. Yakovka River, Yaroslavl' Oblast}

Wood from upper strata of interglacial deposits at mouth of Yakovka R., $2 \mathrm{~km}$ downstream from Chermenino village $\left[58^{\circ} 04^{\prime} \mathrm{N}\right.$ Lat, $38^{\circ} 50^{\prime}$ E Long], Rybinsk Raion, Yaroslavl' Oblast. From gyttja with plant remains, at depth 6.8 to $7 \mathrm{~m}$ below surface. Coll. 1965 by Kh. A. Arslanov, Ye. P. Zarrina, I. I. Krasnov, and V. A. Novskiy.

\section{LG-9. Edoma River, Yaroslavl' Oblast}

Wood from lower layers of alluvium in floodplain terrace of Edoma $\mathrm{R}$. flowing into Volga $\mathrm{R}$. at Bol'shoye Titovskoye village [ca. $57^{\circ} 55^{\prime}$ $\mathrm{N}$ Lat, $39^{\circ} 20^{\prime} \mathrm{E}$ Long] between Rybinsk and Tutayev, at base of gravel overlying till, at depth $13.7 \mathrm{~m}$. Coll. 1965 by Kh. A. Arslanov, Ye. P. Zarrina, I. I. Krasnov, and V. A. Novskiy. 
Date lists:

$\begin{array}{ll}\text { Khlopin Inst. I } & \text { Arslanov, 1968 } \\ \text { Vernadsky Inst. IV-V } & \text { Vinogradov, D }\end{array}$

\section{REFERENCES}

Vinogradov, Devirts, Dobkina, and Markova, 1968

Arslanov, Kh. A., 1968, Khlopin Institute radiocarbon dates I: Radiocarbon, v. 10, no. 2, p. $446-447$.

Arslanov, Kh. A., Gromova, L. I., Novskiy, V. A., 1966a, A more precise dating for Upper Pleistocene deposits in certain cross sections of the Volga in the Yaroslavl' area with $\mathrm{C}^{14}$, in: Grichuk, V. P., Ivanova, I. K., Kind, N. V., and Ravskiy, E. I., (eds.), Verkhniy pleystotsen. Stratigrafiya i absolyutnaya geokhronologiya (The Upper Pleistocene. Stratigraphy and absolute geochronology): Moscow, Izd. “Nauka,” p. 133-140.

Arslanov, Kh. A., Gromova, L. I., and Rudneyev, Yu. A., 1966b, Dates of the Laboratory for Quaternary Geochronology of the All-Union Geological Research Institute, Leningrad, in: Grichuk et al., op. cit., p. 264-265.

Sukachev, V. N., Gorlova, R. N., Metel'tseva, Ye. P., and Novskiy, V. A., 1961, Interglacial deposits in the Rybinsk area, Yaroslavl' Oblast: Doklady Akad. Nauk, v. 140 , no. 6 , p. 427-430.

Vinogradov, A. P., Devirts, A. L., Dobkina, E. I., and Markova, N. G., 1968, Radiocarbon dating in the Vernadsky Institute IV-V: Radiocarbon, v. 10, no. 2, p. 451464. 